\title{
Changes in bacterial and archaeal communities during the concentration of brine at the graduation towers in Ciechocinek spa (Poland)
}

\author{
Agnieszka Kalwasińska ${ }^{1} \cdot$ Edyta Deja-Sikora $^{2} \cdot$ Aleksandra Burkowska-But $^{1} \cdot$ Attila Szabó $^{3} \cdot$ Támas Felföldi $^{3}$. \\ Przemysław Kosobucki $^{4} \cdot$ Arkadiusz Krawiec $^{5} \cdot$ Maciej Walczak $^{1}$
}

Received: 22 September 2017 / Accepted: 8 December 2017 / Published online: 19 December 2017

(c) The Author(s) 2017. This article is an open access publication

\begin{abstract}
This study evaluates the changes in bacterial and archaeal community structure during the gradual evaporation of water from the brine (extracted from subsurface Jurassic deposits) in the system of graduation towers located in Ciechocinek spa, Poland. The communities were assessed with 16S rRNA gene sequencing (MiSeq, Illumina) and microscopic methods. The microbial cell density determined by direct cell count was at the order of magnitude of $10^{7}$ cells $/ \mathrm{mL}$. It was found that increasing salt concentration was positively correlated with both the cell counts, and species-level diversity of bacterial and archaeal communities. The archaeal community was mostly constituted by members of the phylum Euryarchaeota, class Halobacteria and was dominated by Halorubrum-related sequences. The bacterial community was more diverse, with representatives of the phyla Proteobacteria and Bacteroidetes as the most abundant. The proportion of Proteobacteria decreased with increasing salt concentration, while the proportion of Bacteroidetes increased significantly in the more concentrated samples. Representatives of the genera Idiomarina, Psychroflexus, Roseovarius, and Marinobacter appeared to be tolerant to changes of salinity. During the brine concentration, the relative abundances of Sphingobium and Sphingomonas were significantly decreased and the raised contributions of genera Fabibacter and Fodinibius were observed. The high proportion of novel (not identified at $97 \%$ similarity level) bacterial reads (up to $42 \%$ ) in the $16 \mathrm{~S}$ rRNA gene sequences indicated that potentially new bacterial taxa inhabit this unique environment.
\end{abstract}

Keywords Brine $\cdot$ Archaeal community $\cdot$ Bacterial community $\cdot$ Halophiles

\section{Introduction}

Communicated by A. Oren.

Electronic supplementary material The online version of this article (https://doi.org/10.1007/s00792-017-0992-5) contains supplementary material, which is available to authorized users.

Agnieszka Kalwasińska

kala@umk.pl

1 Department of Environmental Microbiology and Biotechnology, Faculty of Biology and Environmental Protection, Nicolaus Copernicus University in Toruń, Lwowska 1, Toruń, Poland

2 Centre of Modern Interdisciplinary Technologies, Nicolaus Copernicus University in Toruń, Wileńska 4, Toruń, Poland

3 Department of Microbiology, Eötvös Loránd University, Pázmány Péter stny. 1/c, H-1117 Budapest, Hungary
Salinity is an environmental factor which varies across natural aquatic systems due to both differences in the ratio of precipitation to evaporation and the input of dissolved ions from an area of land where precipitation collects and drains off into a common outlet. Concentrated salt solutions

4 Department of Food Analysis and Environmental Protection, Faculty of Chemical Technology and Engineering, UTP University of Science and Technology, Seminaryjna 3, Bydgoszcz, Poland

5 Department of Geology and Hydrogeology, Faculty of Earth Sciences, Nicolaus Copernicus University in Toruń, Lwowska 1, Toruń, Poland 
(brines) occur widely in the natural form of coastal lagoons, salt or soda lakes, deep-sea brines, groundwater, as well as in the form of salterns or saltworks of anthropogenic origin. Microorganisms adapted to life at high salt concentrations are found in all three domains of life and use different strategies of haloadaptation (Ma et al. 2010; Zajc et al. 2013; Harding et al. 2016).

The influence of salinity on bacterial and archaeal community composition in saline systems with rapid changes in salinity such as estuaries (Campbell and Kirchman 2013; Crump et al. 2004; Moss et al. 2006), soda pans (Szabó et al. 2017), and coastal solar salterns (Casamayor et al. 2002; Dillon et al. 2013), as well as in habitats with stable salinity conditions, characterized by a slow evolution from freshwater to saline (Felföldi et al. 2016; Máthé et al. 2014; Wu et al. 2006; Xing et al. 2009) has been investigated. These studies have definitively shown that salinity is one of the major factors controlling microbial abundance and diversity.

Groundwater aquifers with high temporal and horizontal stability are extreme habitats that contain microorganisms such as bacteria, archaea or fungi at low cell densities (Beyer et al. 2014). The knowledge on the diversity and functions of microbial communities in saline groundwater is limited. In the present study, we describe changes in bacterial and archaeal communities during the concentration of brine taken from deep subsurface environment (aquifer within Jurassic deposits, $405 \mathrm{~m}$ deep) and subsequently processed in the system of graduation towers.

A graduation tower is a unique structure used to produce salt which removes water from a saline solution by evaporation increasing the concentration of mineral salts. The tower consists of a wooden wall-like frame stuffed with bundles of brushwood (typically Prunus spinosa L.) splitting brine into droplets. The salt water runs down the tower and partly evaporates, and then it is discharged into the salt works. The maximal salt concentration which is practicable to obtain in a temperate climate zone is $27 \%$ and the optimal conditions for the process are sunny weather, temperature above $20{ }^{\circ} \mathrm{C}$, and a gentle wind. Under such favorable conditions, the maximal salt concentration can be achieved within 3 days. Both graduation towers and salterns, which are usually fed by seawater or saltwater springs, are used to produce salt through evaporation of water from a saline solution. Multipond solar salterns consist of a series of interconnected ponds with increasing salinity reaching sodium chloride saturation level (Boujelben et al. 2012, Gomariz et al. 2015), which is significantly higher than in the system of graduation towers. However, in case of graduation towers, the process of brine concentration may be faster, as the volume of saline water passing through is much lower (approximately $15,000 \mathrm{~m}^{3}$ ). Therefore, the changes in salinity observed in the graduation towers may be more rapid, compared to the system of solar salterns.
Solar salterns found worldwide, on the coasts of tropical and subtropical areas, harbor dense communities of extremely halophilic organisms generally dominated by archaea and characterized by low species richness and short food chains (Antón et al. 2000; Burns et al. 2004; Çinar and Mutlu 2016; Oren et al. 1996; Trigui et al. 2011). Contrary to them, the graduation towers can be found only in a few European spas (Poland, Germany, Austria) where they are used mainly as outdoor inhalatoria (Burkowska-But et al. 2014). The currently described community structure in hypersaline environments like solar salterns is that the square archaeon Haloquadratum walsbyi, the bacteroidete Salinibacter ruber and nanohaloarchaea are predominant members at the highest salt concentration, while more diverse archaeal and bacterial taxa are observed in habitats with intermediate salinities (Ventosa et al. 2015).

The present study is the first attempt to reveal the influence of salinity on bacterial/archaeal community composition and diversity in the artificial system of graduation towers with rapid dynamic salinity conditions fed by underground brine taken from Jurassic deposits and to identify bacterial taxa sensitive or tolerant to changes in water salinity.

\section{Materials and methods}

\section{Study area}

There are three graduation towers (Fig. 1) in the center of Ciechocinek (mid-northern Poland coordinates: $\left.52^{\circ} 52^{\prime} 58.2^{\prime \prime} \mathrm{N} 18^{\circ} 47^{\prime} 13.8^{\prime \prime} \mathrm{E}\right)$. The two largest towers were built in 1827-1828 and the third in 1859. Their total length is $1.7 \mathrm{~km}$ (Fig. 2). Their frames were made of oak and pine. Pumps raise brine from a borehole up to 15 meters above the ground level to the gutter on the upper platform. Borehole INT11 is located $400 \mathrm{~m} \mathrm{SE}$ from the first graduation tower and its cover is in the shape of a mushroom and also acts as a fountain. The depth of the borehole drilled in 1909-1911 is $405 \mathrm{~m}$ [middle Jurassic deposits (Krawiec 2009)]. The saline water originates from meteoric waters of warm preQuaternary climates and also cold Quaternary climates with salinity gained from leaching numerous Zechstein salt diapirs (Krawiec 1999; Zuber and Grabczak 1991; Zuber et al. 2007). The temperature of the brine is $15^{\circ} \mathrm{C}$, the concentration of total dissolved solids is $42 \mathrm{~g} / \mathrm{L}$ and its redox potential is $-11 \mathrm{mV}$ (according to the Archive of the Spa, unpublished). The brine is concentrated at the three subsequent graduation towers (GT1-GT3 connected in series) during its way down through blackthorn branches to the lower gutters and then to the bottom tanks at the foot of each tower. Water from the tank GT1 is transferred directly on the top of the GT2 tower and water from the tank GT2 is transferred on the 
Fig. 1 Outlook of the sampling sites

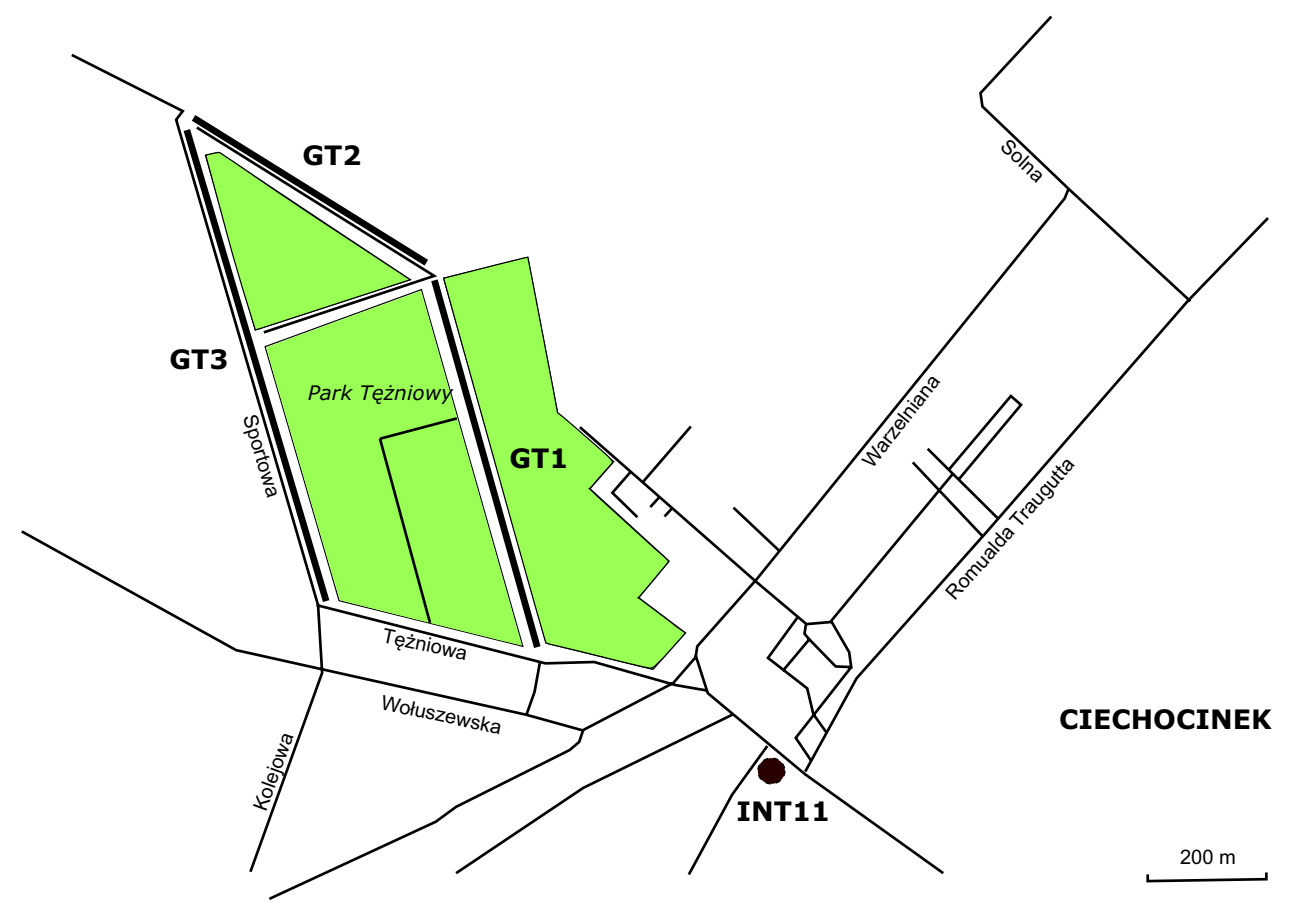

A

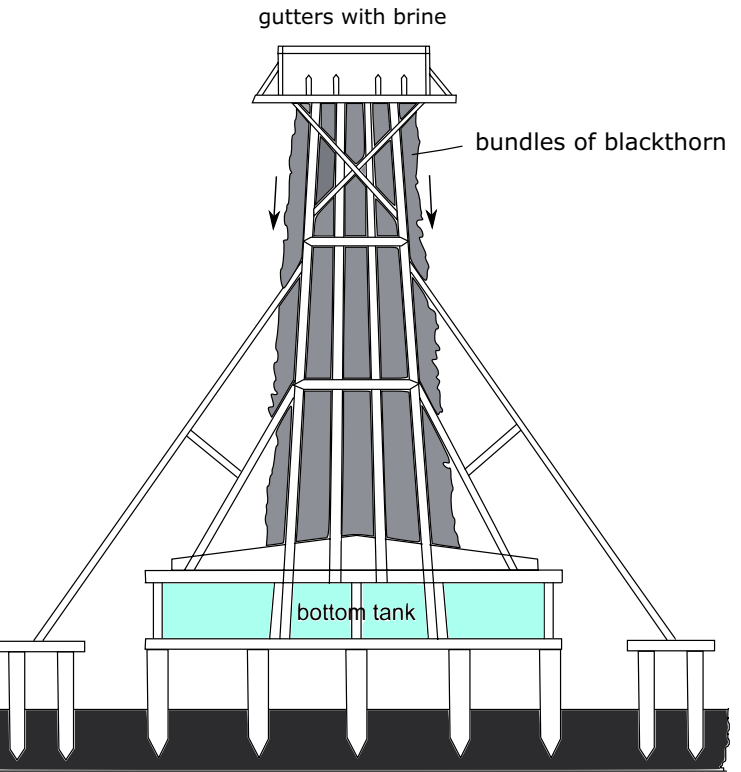

B

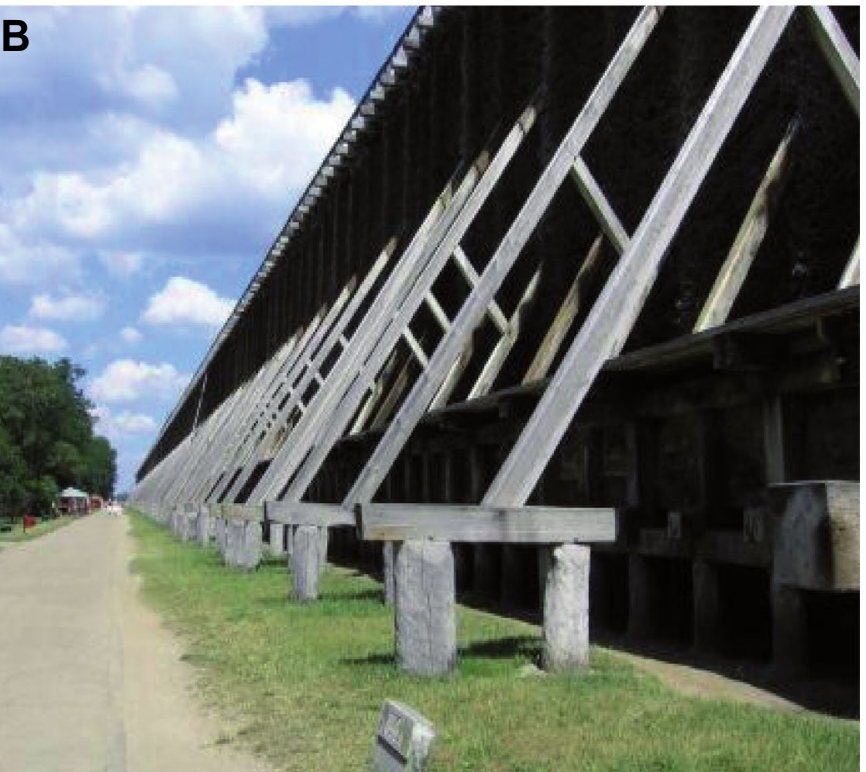

Fig. 2 A graduation tower: a schematic diagram (a) arrows indicate the brine flow; photo (b)

top of GT3 tower. Then the brine is discharged into the salt works. Graduation towers are used not only for the production of salt but also the microclimate around the area close to the towers acts as an inhalatorium or air filter.

\section{Brine samples}

Brine samples were collected at four sampling sites in September 2015 from a wellhead (INT11) and after the concentration of the brine from the bottom tanks at the foot of the three subsequent graduation towers GT1-GT3 (Fig. 1). Samples (10 1) were collected using sterile glass bottles. Prior to the sampling, stagnant water from the borehole was pumped out and valve outlet was flame-sterilized. Bottles were completely filled with water avoiding air bubbles, then tightly sealed and transported directly to the laboratory in a portable ice bag at $4{ }^{\circ} \mathrm{C}$. All analyses started within $2 \mathrm{~h}$ after sample collection. 


\section{Chemical analyses of brine samples}

Total dissolved solids were measured by gravimetric method in $180^{\circ} \mathrm{C}$ and expressed in \% as salinity. Dissolved oxygen was measured with a portable dissolved oxygen meter HI9143, Hanna Instruments (Michigan, USA), pH was determined with an Elmetron $\mathrm{pH}$-meter (Zabrze, Poland) coupled with $\mathrm{H}^{+}$(EPP-1) and $\mathrm{Cl}^{-}$electrodes (Detektor, Poland) according to Knauss et al. (1990). Concentration of total carbon (TC) total organic/inorganic carbon (TOC, TIC) total nitrogen (TN) and ammonia nitrogen $\left(\mathrm{NH}_{4}-\mathrm{N}\right)$ was determined as described in Kalwasińska et al. (2015). All parameters were measured in triplicates.

\section{Enumeration of microorganisms}

For determination of the total microbial cell counts, a $10-\mathrm{mL}$ aliquot of each sample (in 3 replicates) was immediately fixed with formaldehyde at a final concentration of $4 \%$ upon collection. Following an overnight incubation at $4{ }^{\circ} \mathrm{C}$, the fixed samples were filtered through black polycarbonate filters $(0.22-\mu \mathrm{m}$ pore size; Millipore, Bedford MA) and stained with acridine orange (final concentration $0.005 \mathrm{~g} / \mathrm{L}$ ) for $3 \mathrm{~min}$. Microbial cells were counted with an epifluorescence microscope (Nikon Eclipse E200, Japan) at 1000× magnification on 10 randomly selected fields.

\section{Primers design}

For next-generation DNA sequencing (NGS) with an Illumina MiSeq platform amplicons of the $16 \mathrm{~S}$ ribosomal RNA gene were prepared with two pairs of primers used in two rounds of PCRs. Primers were designed in such a way to add unique barcodes (MID multiplex identifier) and sequencing adapters (P5 and P7) to the products. Primers of the firstround PCR contained universal sequences complementary to bacterial (357F: CCT ACG GGA GGC AGC AG and 786R: ACC AGG GTA TCT AAW CC; (Alm et al. 1996; Gołębiewski et al. 2014)) and archaeal (513F: GGT GYC AGC CGC CGC GGT AA and 915R: GTG CTC CCC CGC CAA TTY CT) 16S rRNA genes. Universal sequences were proceeded by M13 sequences (at the 5' ends): GTT TTC CCA GTC ACG AC for F primers and CAG GAA ACA GCT ATG AC for R ones. M13 sequences were used as priming sites in the second round of PCR that was performed with other primers containing from the $3^{\prime}$ ends: M13, multiple identifiers (MID), and P5 (AAT GAT ACG GCG ACC ACC GAG ATC TAC AC) or P7 (CAA GCA GAA GAC GGC ATA CGA GAT) adapters to the MiSeq flow cell.

HPLC-purified PCR primers of the first round were used as custom sequencing primers for read 1 and read 2. Additionally, custom i5 index read primers (786R_i5: GGW TTA GAT ACC CTG GTC CGA CGA CGA CGG TCA TAG
CTG TTT CCT G and 915R_i5: AGR AAT TGG CGG GGG AGC ACG TCA TAG CTG TTT CCT G) were used during sequencing.

\section{Extraction of microbial community DNA}

Water samples $(250 \mathrm{~mL})$ were filtered through sterile polycarbonate filter membranes ( $0.22 \mu \mathrm{m}$ pore size Millipore). Fragmented filters were put into the tubes and used for total genomic DNA isolation using a method described by Zhou et al. (1996). DNA concentration was measured with Qubit 2.0 (Invitrogen) using Qubit dsDNA HS Assay Kit (Thermo Fisher Scientific).

\section{Preparation of 16S rDNA amplicon libraries}

Fragments of bacterial and archaeal 16S rDNA sequences were generated by the following PCR protocol. Reaction mixtures contained: $1 \mu \mathrm{L}$ of metagenomic DNA, $0.2 \mathrm{mM}$ dNTPs, $0.25 \mu \mathrm{M}$ primers of the first round, $1 \mathrm{U}$ High Fidelity Phusion Polymerase, and $1 \times$ buffer with $1.5 \mathrm{mM} \mathrm{MgCl}_{2}$ (Thermo Fisher Scientific). Thermal profile of the reaction contained: initial denaturation at $98^{\circ} \mathrm{C}$ for $30 \mathrm{~s} ; 30$ cycles of $-98^{\circ} \mathrm{C}$ for $10 \mathrm{~s}, 55^{\circ} \mathrm{C}$ (bacterial primers) $/ 62.5^{\circ} \mathrm{C}$ (archaeal primers) for $15 \mathrm{~s}, 72{ }^{\circ} \mathrm{C}$ for $10 \mathrm{~s}$; and final elongation at $72{ }^{\circ} \mathrm{C}$ for $5 \mathrm{~min}$. The concentration of product was measured with Qubit 2.0 and Qubit dsDNA HS Assay Kit. $50 \mathrm{pg}$ of amplicons from each reaction were used for another PCR round containing: $0.2 \mathrm{mM}$ dNTPs $0.25 \mu \mathrm{M}$ second-round primers $1 \mathrm{U}$ Taq Polymerase and 1x buffer with $1.5 \mathrm{mM}$ $\mathrm{MgCl}_{2}$ (Thermo Fisher Scientific). Cycling conditions were following: initial denaturation at $95^{\circ} \mathrm{C}$ for $3 \mathrm{~min} ; 15$ cycles of $-95^{\circ} \mathrm{C}$ for $30 \mathrm{~s}, 54{ }^{\circ} \mathrm{C}$ for $20 \mathrm{~s}, 72^{\circ} \mathrm{C}$ for $30 \mathrm{~s}$; and final elongation at $72{ }^{\circ} \mathrm{C}$ for $5 \mathrm{~min}$. Then the concentrations of 16S rDNA amplicons were measured as mentioned before.

Bacterial and archaeal libraries were created by pooling equal quantities of amplicons. Libraries were double purified with Agencourt AMPure XP (Agencourt Bioscience) and evaluated using a model 2100 Bioanalyzer (Agilent Technologies) with a High Sensitivity DNA Analysis Kit (Agilent Technologies).

\section{Library quantification and sequencing}

16S rRNA gene amplicons were quantified with the KAPA DNA Library Quantification Kit (KAPA Biosystems). Reaction mixtures were prepared according to the manufacturer's protocol. Quantification run was performed on a Roche LightCycler 480 System. Bacterial and archaeal libraries were pooled in equimolar ratio and diluted to obtain a single 6 pM sequencing library per sample with $10 \%$ PhiX DNA. Sequencing was performed on a MiSeq platform (Illumina) using a MiSeq Reagent Kit v3 (600 cycles). HPLC-purified 
custom sequencing primers were mixed with Illumina primers. Demultiplexing of indexed reads was performed with the MiSeq software.

\section{Bioinformatics analysis}

Sequence reads were processed using mothur v1.35 (Schloss et al. 2009) as recommended by the MiSeq SOP page (http://www.mothur.org/wiki/MiSeq_SOP downloaded at 25/01/2016) (Kozich et al. 2013). Sequences obtained with the Archaea- and Bacteria-specific primers were assorted based on the alignment using the ARB-SILVA SSU NR99 reference database-SILVA release 123 (Quast et al. 2013). Chimera detection was performed with UCHIME (Edgar et al. 2011). Besides chimeric sequences, singleton reads were also removed (using mothur's 'split.abund' command) according to Kunin et al. (2010). Taxonomic assignments were made against SILVA release 123 applying a minimum bootstrap confidence score of $80 \%$. Operational taxonomic units (OTUs) were assigned at $97 \%$ similarity threshold level as suggested by Tindall et al. (2010) for prokaryotic species delineation. Raw sequence reads were deposited in NCBI SRA under BioProject ID PRJNA383523.

\section{Calculating the richness and diversity of the total bacterial and archaeal community}

Species richness Chao1 (Chao 1984) and ACE (Chao and Lee 1992) indices were assessed at the 0.03 dissimilarity level (representing a threshold value for bacterial species according to Tindall et al. 2010) with the mothur software (Schloss et al. 2009) for thousand-fold randomized subsamples of 3163 sequences/sample for Bacteria and 967 sequences/sample for Archaea. Bray-Curtis (Bray and Curtis 1957) and Morisita-Horn (Horn 1966) dissimilarities were calculated for all the pairs of samples using vegan (Oksanen et al. 2017) in R v 3.3.1 and visualized via corrplot in $R$ (Wei and Simko 2016). Venn diagrams were generated from the shared OTU (operational taxonomic unit) table using a web interface for creating Venn diagram from Gent University (http://bioinformatics.psb.ugent.be/webtools/Venn/).

\section{Statistical analysis}

The differences between values of microbial densities and species richness/diversity estimators were tested with oneway ANOVA and the pairwise differences were checked with Tukey HSD test (Statistica 97 ver. 6.0). Spearman's correlation coefficients between physico-chemical parameters of the brines and bacterial/archaeal diversity were performed in R using Hmisc package (Spearman's correlation in rcorr; (Harrell 2016)). Principal component analysis (PCA) was carried out using FactoMineR in R (Lê et al. 2008). Principal Coordinates Analysis (PCoA) was performed using Vegan (Oksanen et al. 2017). The envfit function was used to link microbial community composition (OTUs at the 0.03 level) to the environmental variables. Environmental data were standardized using $\mathrm{z}$-scoring and correlation matrix of environmental variables was calculated prior to PCA and PCoA. Parameters showing strong positive correlation $(\geq 0.8)$ were reduced to one variable representing both of them and expressed on the diagram as TC/TIC.

\section{Results}

\section{Brine characteristics}

Physicochemical characteristics of brines are presented in Table 1. Although the samples had quite similar neutral $\mathrm{pH}$ values (between 6.6 and 7.4), they differed much regarding the concentration of salt. Brine from the borehole (INT11) feeding the first graduation tower had the lowest salinity $(5.1 \pm 0.02 \%)$, while brine from the last sampling site (GT3) had the highest salinity $(26.7 \pm 1.75 \%)$. Groundwater from the borehole (INT11) did not contain dissolved

Table 1 Chemical properties of the brines from Ciechocinek

\begin{tabular}{|c|c|c|c|c|c|c|c|c|c|}
\hline Sample code & Salinity (\%) & DO (ppm) & $\mathrm{pH}$ & $\mathrm{TC}(\mathrm{mg} / \mathrm{L})$ & TOC (mg/L) & TIC (mg/L) & $\mathrm{TN}(\mathrm{mg} / \mathrm{L})$ & $\mathrm{NH}_{4}-\mathrm{N}(\mathrm{mg} / \mathrm{L})$ & $\begin{array}{l}\text { Density of } \\
\text { microor- } \\
\text { ganisms } \\
(\text { cells } / \mathrm{mL}, \\
\left.10^{7}\right)\end{array}$ \\
\hline INT 11 & $5.1 \pm 0.02$ & $<$ LOD & $7.05 \pm 0.02$ & $141.0 \pm 2.87$ & $68.3 \pm 3.17$ & $61.7 \pm 1.56$ & $7.7 \pm 0.02$ & $0.035 \pm 0.002$ & $2.25 \pm 1.05$ \\
\hline GT1 & $8.7 \pm 0.9$ & $4.13 \pm 0.07$ & $6.62 \pm 0.03$ & $88.23 \pm 1.11$ & $48.2 \pm 1.24$ & $40.0 \pm 0.74$ & $10.6 \pm 0.02$ & $0.039 \pm 0.001$ & $2.96 \pm 0.26$ \\
\hline GT2 & $16.4 \pm 1.5$ & $1.92 \pm 0.03$ & $7.39 \pm 0.04$ & $91.25 \pm 2.13$ & $61.7 \pm 2.08$ & $29.6 \pm 0.89$ & $8.8 \pm 0.01$ & $0.037 \pm 0.002$ & $3.35 \pm 0.84$ \\
\hline GT3 & $26.7 \pm 1.7$ & $1.14 \pm 0.04$ & $7.15 \pm 0.03$ & $116.90 \pm 1.89$ & $90.4 \pm 1.72$ & $26.5 \pm 0.90$ & $9.5 \pm 0.02$ & $0.040 \pm 0.004$ & $5.47 \pm 0.46$ \\
\hline
\end{tabular}

Each value was calculated based on the results of three parallel measurements

$D O$ dissolved oxygen, $T C$ total carbon; TOC total organic carbon, $T I C$ total inorganic carbon, $T N$ total nitrogen, $\mathrm{NH}_{4}-\mathrm{N}$ ammonia nitrogen, $L O D$ limit of detection, INT11 sample collected from the borehole, GT1-GT3 bottom tank samples collected from the three graduation towers 
oxygen (DO), but after passing through the system of graduation towers, the concentration of dissolved oxygen varied between $4.13 \pm 0.07 \mathrm{ppm}$ and $1.14 \pm 0.04 \mathrm{ppm}$. With the increase in salt concentration, a clear decline in TIC values in the samples was observed (from 61.7 to $26.5 \mathrm{mg} / \mathrm{L}$ ), while TOC starting from GT1 to GT3 showed a rising trend (from 48.2 to $90.4 \mathrm{mg} / \mathrm{L}$ ). Nutrient concentrations varied only slightly across sites. The lowest concentration of TN was recorded in INT11 $(7.7 \mathrm{mg} / \mathrm{L})$ and the highest in sample GT1 $(10.6 \mathrm{mg} / \mathrm{L})$. The concentration of $\mathrm{NH}_{4}-\mathrm{N}$ was very similar at the sites (from 0.035 to $0.040 \mathrm{mg} / \mathrm{L}$ ). TC and TIC were positively and significantly correlated $(R 2=0.8 p<0.05$; data not shown).

The principal component analysis of physicochemical data showed the distinct dispersion of the sampling sites (Fig. S1). The first and the second PCA axis taken together explained $91.5 \%$ of the observed variation (49.9 and $41.6 \%$, respectively). The brine from the sampling site GT3 was the most distinct sample and it was characterized by the highest salinity. Due to a low sample size, the significance of the environmental factors was not tested.

\section{Abundance of microorganisms}

The microbial cell density determined by direct cell count ranged from $2.24 \pm 1.05 \times 10^{7} \mathrm{cell} / \mathrm{mL}$ (sample with the lowest salt concentration) to $5.47 \pm 0.46 \times 10^{7}$ cells $/ \mathrm{mL}$ (the most saline sample Table 2) and was positively correlated with EC $(R 2=0.82 p<0.01)$ and negatively correlated with TIC $(R 2=-0.82 p<0.01)$. The total number of microbes at site GT3 differed significantly from the values measured at other sites $(p<0.01)$.

\section{Bacterial and archaeal community structures}

After quality filtering, 20,636 and 9476 high-quality bacterial and archaeal reads were acquired, respectively, from a total of 4 brine samples (Table 2). The communities were moderately sampled, indicating that more reads would be required to capture all the diversity, especially in case of sampling sites GT2 and GT3 (Fig. S2). Clustering at 97\% similarity level resulted in total 328 bacterial and 132 archaeal OTUs. Both the observed (Sobs) and estimated total richness (ACE Chao1) of bacterial and archaeal communities increased with the increasing salt concentration and were the highest in sample GT2 (Table 2). However, in sample GT3, which had the highest salinity, these values were in between the values of samples GT1 and GT2. In case of bacterial and archaeal diversity (i.e. Shannon and Inverse Simpson's) values were the highest in the most saline sample (GT3). Regression analysis showed that the salinity positively correlated with all estimators of bacterial species richness and diversity (Table 3), and with archaeal diversity indices. Another environmental factors significantly correlating with mentioned above bacterial estimators were $\mathrm{pH}$ and TOC (positive correlation) as well as TIC (negative correlation). In case of archaeal communities a strong negative correlation between archaeal diversity and TIC/TN was found, as well as with DO. However, due to the low number of samples, such results should be treated cautiously in spite of their high statistical significance.

An analysis of the distribution of the most abundant bacterial phyla revealed that the brines from the system of graduation towers were dominated by Proteobacteria and Bacteroidetes (Fig. 3). The contribution of Proteobacteria decreased with increasing salt concentration (R Spear$\operatorname{man}=-0.95 p<0.05)$. Contrary to this, the proportion of Bacteroidetes increased significantly in more concentrated samples (R Spearman $=0.89 p<0.001$ ). The most abundant classes across the samples were Gammaproteobacteria and Alphaproteobacteria followed by Flavobacteriia. These two proteobacterial classes taken together were dominating in INT11 and GT1 (> 80\% of the communities), while their levels were much lower in GT2 and GT3 $(<45 \%)$. The water that passed through the second graduation tower had the highest relative abundance of Flavobacteriia and

Table 2 NGS data statistics of the brine samples from Ciechocinek

\begin{tabular}{|c|c|c|c|c|c|c|c|c|c|}
\hline & Sample code & $\begin{array}{l}\text { Number of } \\
\text { sequences }\end{array}$ & $\begin{array}{l}\text { Good's } \\
\text { coverage } \\
(\%)\end{array}$ & Sobs & $\mathrm{ACE}$ & Chao 1 & $\begin{array}{l}\text { Inverse Simpson's } \\
(1 / D)\end{array}$ & $\begin{array}{l}\text { Shannon's } \\
\text { diversity } \\
\left(H^{\prime}\right)\end{array}$ & Shannon's evenness $(E)$ \\
\hline \multirow[t]{4}{*}{ Bacteria } & INT 11 & 6096 & 99.6 & $59 \pm 2$ & $69 \pm 6$ & $65 \pm 5$ & $5.42 \pm 0.11$ & $2.31 \pm 0.02$ & $0.57 \pm 0.006$ \\
\hline & GT1 & 5495 & 99.7 & $96 \pm 1$ & $102 \pm 2$ & $98 \pm 1$ & $9.25 \pm 0.10$ & $3.10 \pm 0.01$ & $0.68 \pm 0.002$ \\
\hline & GT2 & 5046 & 99.1 & $162 \pm 2$ & $182 \pm 5$ & $173 \pm 5$ & $7.74 \pm 0.11$ & $3.01 \pm 0.02$ & $0.59 \pm 0.003$ \\
\hline & GT3 & 3999 & 99.7 & $127 \pm 1$ & $131 \pm 1$ & $128 \pm 1$ & $14.13 \pm 0.01$ & $3.33 \pm 0.01$ & $0.69 \pm 0.001$ \\
\hline \multirow[t]{3}{*}{ Archaea } & GT1 & 989 & 99.9 & $8 \pm 1$ & $9 \pm 1$ & $8 \pm 1$ & $4.56 \pm 0.1$ & $1.63 \pm 0.01$ & $0.79 \pm 0.001$ \\
\hline & GT2 & 5039 & 99.9 & $73 \pm 4$ & $109 \pm 21$ & $99 \pm 14$ & $10.94 \pm 0.53$ & $2.98 \pm 0.04$ & $0.70 \pm 0.008$ \\
\hline & GT3 & 3448 & 99.7 & $68 \pm 3$ & $107 \pm 23$ & $89 \pm 12$ & $11.94 \pm 0.45$ & $2.98 \pm 0.04$ & $0.71 \pm 0.007$ \\
\hline
\end{tabular}

The number of OTUs found in the subset of sequences was normalized to the sample with the lowest sequence count 
Table 3 Spearman's correlation coefficients between physicochemical parameters of the brines and bacterial/archaeal richness and diversity values

\begin{tabular}{llllllrr}
\hline \multicolumn{1}{c}{} & $\mathrm{pH}$ & Salinity & $\mathrm{DO}$ & $\mathrm{TOC}$ & $\mathrm{TIC}$ & $\mathrm{TN}$ & $\mathrm{NH}_{4}-\mathrm{N}$ \\
\hline Bacteria & & & & & & \\
$S_{\mathrm{obs}}$ & $0.76^{* *}$ & $0.76^{* *}$ & 0.40 & 0.01 & $-0.72^{* *}$ & 0.22 & 0.36 \\
$H^{\prime}$ & $0.67^{*}$ & $0.69^{*}$ & -0.47 & $0.73^{* *}$ & $-0.78^{* *}$ & -0.28 & -0.11 \\
$1 / D$ & $0.73^{* *}$ & $0.73^{* *}$ & -0.42 & $0.73^{* *}$ & $-0.81^{* *}$ & -0.24 & -0.06 \\
Archaea & & & & & & & \\
$S_{\text {obs }}$ & $0.75^{*}$ & 0.60 & -0.50 & 0.40 & -0.50 & $-0.85^{* *}$ & -0.27 \\
$H^{\prime}$ & $0.61^{*}$ & $0.68^{*}$ & $-0.85^{* *}$ & 0.61 & $-0.85^{* *}$ & $-0.85^{* *}$ & -0.58 \\
$1 / D$ & 0.57 & $0.72^{*}$ & $-0.92^{* *}$ & 0.72 & $-0.92^{* * *}$ & $-0.77^{*}$ & -0.52 \\
\hline$* p<0.5, * * p<0.01, * * * p<0.001$ & & & & &
\end{tabular}

INT11
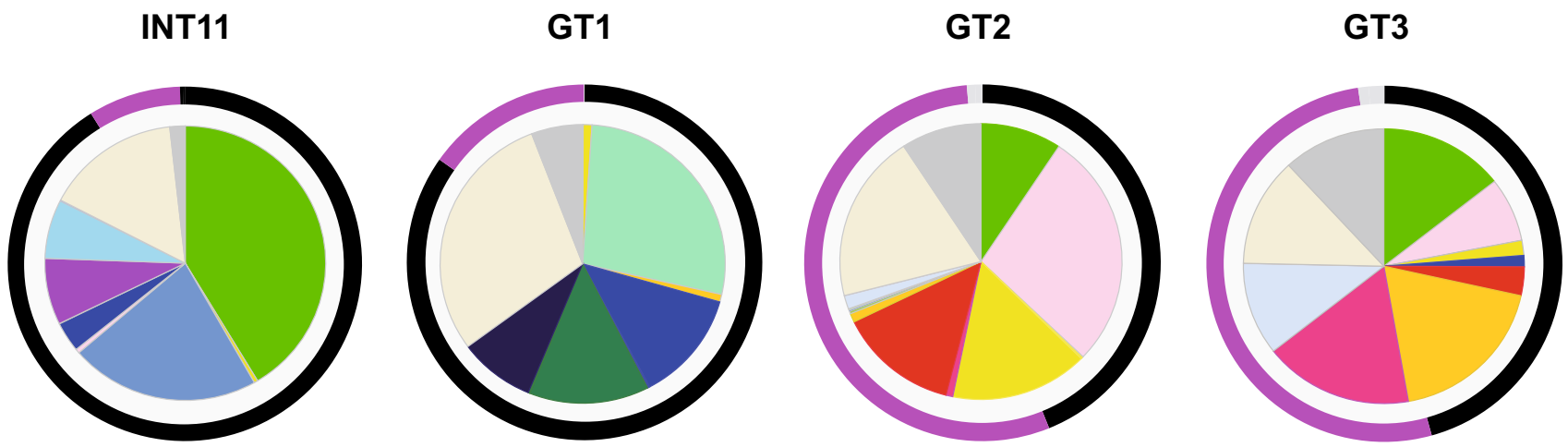

\section{Phylum level}

Proteobacteria Bacteroidetes Others

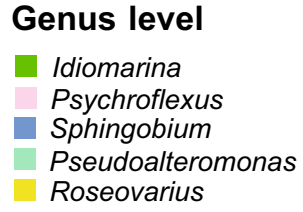

Genus level

Psychroflexus

Pseudoalteromonas

Roseovarius

Marinobacter
Fabibacter
unc. genus, Order III, Cytophagia
Fodinibius

Fodinibius

Chryseobacterium

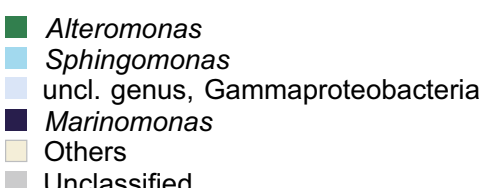

Alteromonas

Sphingomonas

Marinomonas

Unclassified

Fig. 3 Phylum and genus level distribution of NGS reads within the domain Bacteria in the brine samples from Ciechocinek

increased level of Cytophagia (35 and 16\%, respectively). However, the highest representation of Cytophagia (40.2\%) was detected in the sample GT3. Detailed analysis of the bacterial community composition at the genus level showed that the percentage of unclassified bacterial sequences $(2$, 6,12 and $42 \%$ of total bacterial reads) increased with salinity. Many of these sequences were only classified down to class or family level, which means that new phylotypes exist in the studied brines. Shannon's evenness ranged from 0.57 to 0.69 (for INT11 and GT3, respectively), which suggested that a few bacterial species dominated the assessed microbiomes. The bacterial community of the groundwater (INT11) was dominated by Idiomarina, Sphingobium, Sphingomonas, and Chryseobacterium before entering the GT1-GT3 system (Fig. 3, Table S1). The flow of the groundwater brine through the first graduation tower resulted in a loss of the groundwater-specific genera mentioned above. We observed the raised level of Marinobacter, Roseovarius,
Pseudoalteromonas, Alteromonas, and Marinomonas in the GT1 sample. Interestingly Roseovarius reached the highest level in the GT2 sample whereas the proportions of the other genera found in GT1 strongly decreased when the concentration of the brine raised in the next two graduation towers. Generally, GT2 and GT3 communities differed markedly from the GT1. We noticed the resurgence of Idiomarina and co-occurrence of Psychroflexus Fabibacter, Fodinibius, unclassified Gammaproteobacteria, and Cytophagia in the GT2-GT3 communities. However, Psychroflexus, Fabibacter, and Roseovarius were dominant in the GT2 sample, while Fodinibius, Idiomarina, and two unclassified genera belonging to Gammaproteobacteria and Cytophagia were the most abundant in the GT3 sample.

Archaeal reads were detected in all brine samples except INT11. They were dominated by members of the phylum Euryarchaeota (Fig. 4), class Halobacteria. Only a small percentage of reads at the site GT2 $(1.8 \%)$ belonged to 
Fig. 4 Phylum and genus level distribution of NGS reads within the domain Archaea in the brine samples from Ciechocinek
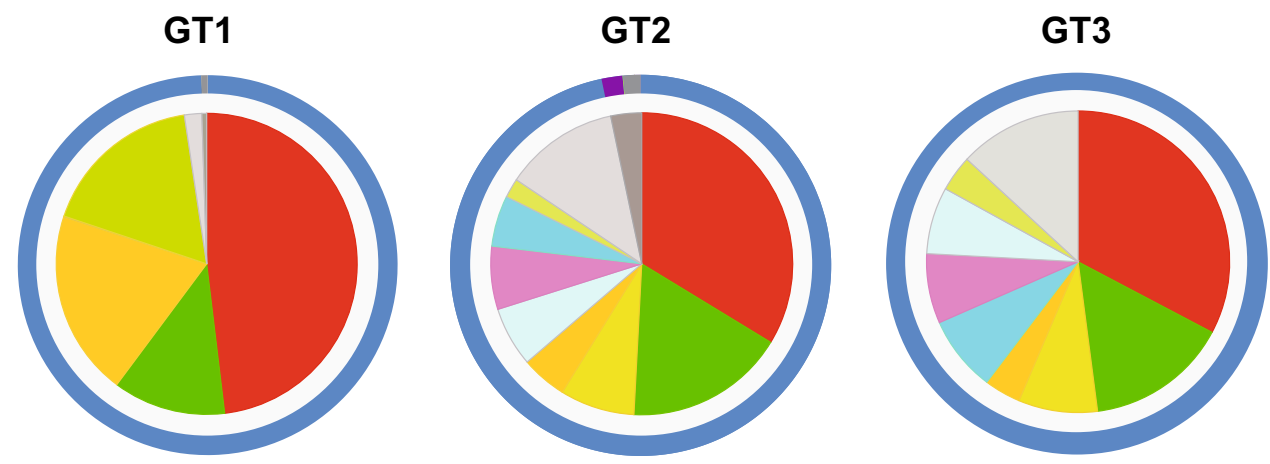

Phylum level

Euryarchaeota

Woesearchaeota (DHVEG-6)

Unclassified

\section{Genus level}

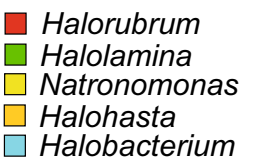

Haloplanus

unclas. Halobacteriaceae

Halonotius

Others

Unclassified unclassified members of the phylum Woesearcheota. Shannon's evenness of archaeal assemblages varied between 0.70 and 0.79 (for GT2 and GT1, respectively) which suggested that a few archaeal species dominated. The most abundant genera in all samples were Halorubrum Halohasta Halonotius and Halolamina (Fig. 4, Table S1). The proportion of the first three genera markedly decreased in more concentrated brines. On the other hand sequences related to Natronomonas Halobacterium Haloplanus and unclassified Halobacteriaceae increased and co-occurred in the GT2-GT3 communities. Interestingly, GT2 and GT3 communities differed significantly from GT1 and were characterized by a very similar pattern of distribution of the most abundant genera.

Incidence- as well as abundance-based distances: Bray-Curtis (B-C) and Morisita-Horn (M-H), respectively, were used to calculate dissimilarities between the communities in the samples and community similarity heatmaps were generated (Fig. S3 and Fig. S4). In case of archaeal communities the B-C similarities were smaller than the $\mathrm{M}-\mathrm{H}$ ones indicating that the structures of the abundant OTUs were more similar than the rare OTUs community structures. Furthermore, the values of $\mathrm{B}-\mathrm{C}$ and $\mathrm{M}-\mathrm{H}$ similarities were higher in case of archaeal communities compared to bacterial communities. In other words, bacterial communities were more dissimilar among sites than archaeal communities. GT2 and GT3 appeared to be the most similar samples while INT11 and GT1 showed little similarity to the others. In case of archaeal communities, samples GT2 and GT3 had almost the same taxonomic composition and GT1 differed from them. A similar pattern of separation of the bacterial and archaeal community composition was shown by PCoA biplots (Fig. 5). The results of the community "overlaps" depicted as Venn diagrams (Fig. 6) corroborated with the analyses presented above. Only 4 bacterial and 6 archaeal OTUs were shared by all four samples. The most abundant shared bacterial OTUs at 0.03 clustering level were $P$ sychroflexus (OTU2), Idiomarina (OTU5), and Roseovarius (OTU6). Among archaeal sequences the most abundant shared OTUs were Halorubrum (OTU1, OTU2), Halolamina (OTU4), Halohasta (OTU6), and Halonotius (OTU7).

\section{Discussion}

The densities of microorganisms in brines were relatively high on average $10^{7}$ cells $/ \mathrm{mL}$. They were similar to those detected in the solar salterns throughout the world (Oren et al. 1996; Antón et al. 2000; Burns et al. 2004; Trigui et al. 2011; Máthé et al. 2014; Andrei et al. 2015; Gomariz et al. 2015; Felföldi et al. 2016; Çinar and Mutlu 2016). Hypersaline environments of greater abundance of microorganisms (more than $10^{8}$ cells $/ \mathrm{mL}$ ) are also known (Guixa-Boixareu et al. 1996; Ochsenreiter et al. 2002). This high density of cells in many hypersaline environments is thought to be a result of the lack of predation and the presence of high nutrient levels (Oren 2002). The total number of microorganisms in the sample from the borehole (INT11) feeding the graduation towers was two or three orders of magnitude higher than the densities recorded in the case of many other terrestrial subsurface environments $\left(10^{4}-10^{5}\right.$ cells $\left./ \mathrm{mL}\right)$ (Beaton et al. 2016; Pedersen and Ekendahl 1990; Walczak et al. 2017); however, the total number of microorganisms close to $10^{4}$ cells $/ \mathrm{mL}$ may be the limit value in groundwaters with a very low concentration of organic carbon (Fry et al. 1997; Lovley and Goodwin 1988). The mean concentration of TOC in natural European groundwaters is relatively low $-2 \mathrm{mg} / \mathrm{L}$ with minimum and maximum values below 0.5 
A

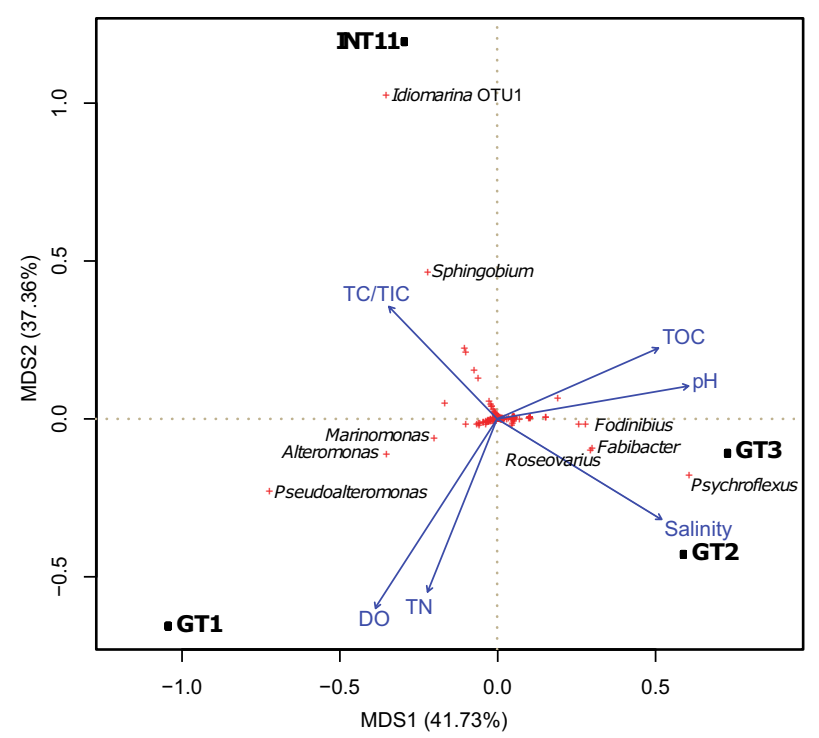

B

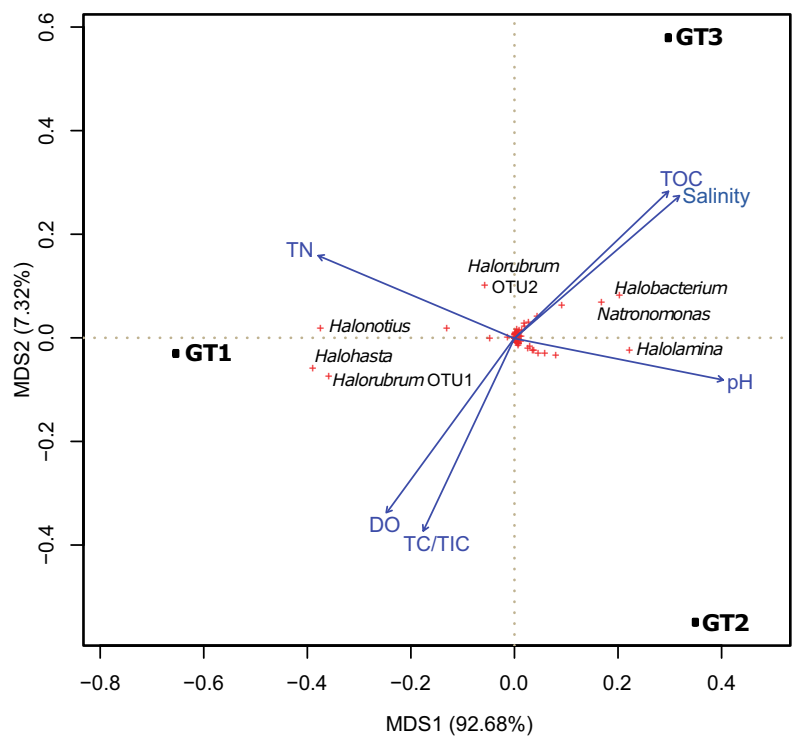

Fig. 5 Principal coordinates analysis (PCoA) of the bacterial (a) and archaeal (b) communities based on the Bray-Curtis distance matrix

Fig. 6 Venn diagrams of shared bacterial (a) and archaeal (b) OTUs at 0.03 dissimilarity level
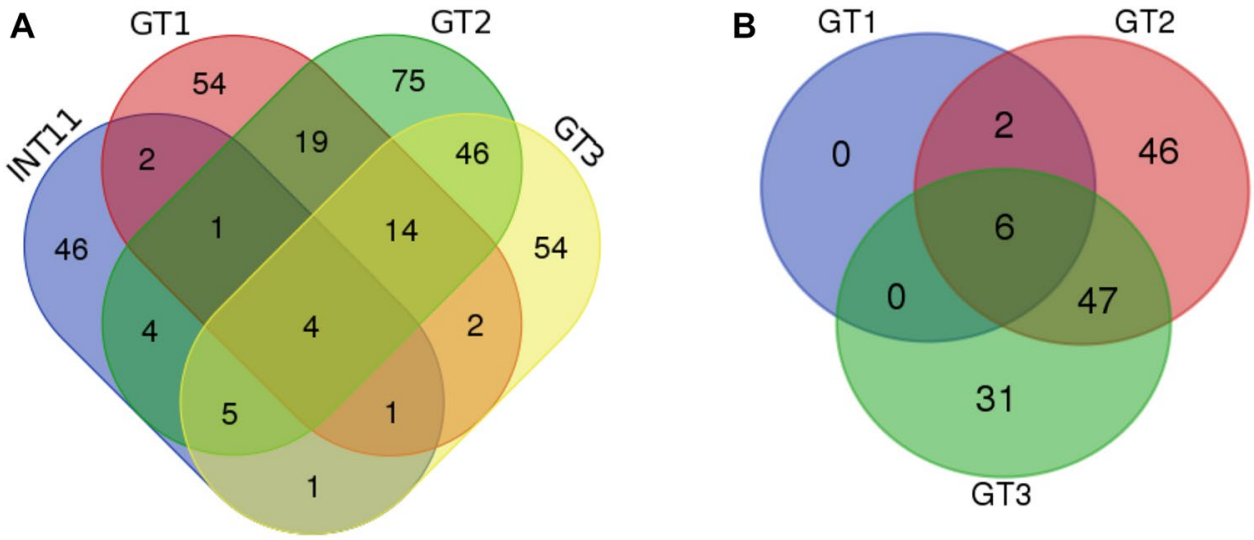

and above $50 \mathrm{mg} / \mathrm{L}$, respectively (Gooddy and Hinsby 2008). The relatively high TOC concentrations in the investigated brines from 48 to $90 \mathrm{mg} / \mathrm{L}$ may explain the high abundance of microorganisms, presumably heterotrophic microorganisms present in the samples.

A widely held ecological tenet states that a more extreme environment is expected to maintain lower species diversity (Frontier 1985). However, this is not the case here. Both the observed, and estimated bacterial species richness and diversity in the studied samples increased along the salinity gradient (5-27\%). Similar findings were recorded by other researchers in solar salterns (Casamayor et al. 2002; Øvreås et al. 2003), but in the ponds with the highest degree of salt concentration (around $35-37 \%$ crystallizer ponds), the richness of taxa at the genus level was usually reduced, compared with ponds of lower salinity and often resulted in a few dominant phylotypes (Çinar and Mutlu 2016; Ventosa et al. 2015). Contrary to the observed significant positive correlation between bacterial species richness/diversity and salinity, there was no such statistical relationship in case of archaeal communities in the investigated brines. The archaeal communities, especially GT2 and GT3, were more similar among sites than the bacterial ones. Similar observation was made by Hoshino et al. (2011), and Purkamo et al. (2016) who compared bacterial and archaeal communities in subsurface environments.

Archaeal communities of the brines from the system of graduation towers in Ciechocinek were dominated by members of Euryarchaeota (Halobacteriaceae), which is in line with reports of other authors studying microbial diversity in environments with a broad range (3-37\%) of salinity gradient (e.g., Ventosa et al. 2015). The comparative analysis of prokaryotic communities of salterns of a medium salinity (20-27\%) in Turkey, based on high-throughput 16S rDNA 
amplicon sequencing data, and two medium concentrators in Tunisia and Spain (salinity 20-28 and 18-29\%, respectively), based on DGGE present similar findings, with all archaeal sequences assigned to the class Halobacteria and family Halobacteriaceae (Çinar and Mutlu 2016; Boujelben et al. 2012; Gomariz et al. 2015). Nevertheless, we observed that the GT2-GT3 (salinity 16 and 27\%, respectively) pattern of taxa distribution differed from the less concentrated GT1 (9\%) and comprised quite evenly distributed sequences related to Natronomonas, Halohasta, Halobacterium, and Haloplanus. The similar structure of archaeal assemblages may manifest a stabilization of the community composition at the genus level at the elevated levels of salinity.

Interestingly, the study of the graduation towers microbiome revealed considerable novelty. There was no evidence of the presence of sequences belonging to the genus Haloquadratum that usually dominates microbial communities in hypersaline waters, close to or above saturation, but is also present in medium salinity brines (Dyall-Smith et al. 2011; Ventosa et al. 2015; Podell et al. 2014; Gomariz et al. 2015). The most abundant archaeal reads in our samples belonged to the hyperhalophilic genera Halorubrum and Halolamina. Representatives of the genus Halorubrum dominated over Haloquadratum in the two Turkish salterns Fadlum and Tuzlagözü (salinity 27 and 20\%, respectively, Çinar and Mutlu 2016), as well as in the Spanish saltern SS19 Santa Pola with medium salinity (19\%, Ghai et al. 2011). The second more abundant archaeal genus in brines from graduation towers in Ciechocinek was Halolamina while in the case of Turkish salterns sequences related to this genus constituted only a minor fraction of the archaeal dataset (Çinar and Mutlu 2016). Representatives of the genus Halolamina were first isolated from the Taibei marine solar saltern, China (Cui et al. 2011) and were also found in purified solar salt and crystallizing pond of Gomso solar saltern, Republic of Korea (Cha et al. 2014; Park et al. 2012). Therefore, their presence in the hypersaline environment studied here is explainable.

It should also be pointed that archaeal reads were not detected in the sample taken from the borehole (INT11), suggesting that the representatives of the domain Archaea may not be present there or were present at low abundance. It would not be surprising in case of Halobacteriaceae which prevailed in other samples. Members of this family are thought to be obligate halophiles (Oren 2008) and may be more demanding in terms of high salt concentration than the concentration found in the brine from the borehole. On the other hand, Archaea are more cosmopolitan in nature than was previously thought (e.g. DeLong 1992) and were also detected in a low-salt subsurface environment (Chaudhary et al. 2009; Elshahed et al. 2004; Fry et al. 2008).

Bacterial communities of the brines from the system of graduation towers in Ciechocinek were dominated by the phyla Proteobacteria and Bacteroidetes. The proportion of Proteobacteria (especially class Alphaproteobacteria) decreased with increasing salt concentration, while the proportion of Bacteroidetes increased significantly in the more concentrated samples (up to 27\%), which is consistent with the data reported by other authors (Çinar and Mutlu 2016; Ventosa et al. 2015; Gomariz et al. 2015; Fernández et al. 2014). Single-cell genome analysis of some members of Bacteroidetes described by Gomariz et al. (2015) suggested a set of metabolic features which may be responsible for competitive advantages in hypersaline environments, such as polymer degradation capabilities, the presence of retinal-binding, light activated proton pumps and also arsenate reduction potential.

Our research demonstrated that a few bacterial taxa namely Idiomarina, Psychroflexus, Roseovarius, and Marinobacter appeared over a wide salinity range, i.e., 4.5-27\% showing their broad ecological plasticity. Indeed their representatives have been isolated from a variety of environments starting from estuaries and seawater to hypersaline crystallizer ponds (Lee et al. 2015; Máthé et al. 2014; Park et al. 2016; Zhong et al. 2015). On the other hand, one of the possible microbial community responses to increasing salinity is the replacement of suboptimally adapted taxa by taxa better adapted to the given salinity conditions (Wu et al. 2006). This can clearly be seen, for instance, in the composition of the first two samples INT11 and GT1. Sphingomonas and Sphingobium-related sequences (Alphaproteobacteria) which were abundant in the underground brine of a lower salinity (4.5\%) were replaced by Alteromonas and Pseudoalteromonas-related sequences (Gammaproteobacteria) in the more concentrated brine sample $\mathrm{GT} 1(9 \% \mathrm{NaCl})$. According to the physiological data on $\mathrm{NaCl}$ tolerance of particular bacterial strains available in LPNS database (List of Prokaryotic Names with Standing in Nomenclature; http:// www.bacterio.net) Sphingomonas and Sphingobium show significantly lower salt tolerance (usually up to $1 \% \mathrm{NaCl}$ ) than Alteromonas and Pseudoalteromonas (up to 15-20\% $\mathrm{NaCl}$ and $6-13 \% \mathrm{NaCl}$, respectively).

The gradual adaptation of the same taxa which is another possible response to increasing salinity may be particularly noticeable in case of Salegentibacter (OTU018). This genus encompasses both moderately halophilic and highly halotolerant bacteria (Ivanova et al. 2006; Yoon et al. 2008).

The relatively high percentage of novel bacterial reads in the more concentrated samples that reached $42 \%$ of total bacterial sequences at the genus level in GT3 is remarkable for the obtained dataset. This is a significantly higher level of novel reads than previously noted for solar salterns (Çinar and Mutlu 2016; Fernández et al. 2014; Podell et al. 2014), which indicate that potentially new bacterial taxa inhabit this unique environment. On the other hand, the number of novel archaeal reads obtained for the GT2 and GT3 datasets was significantly lower and did not exceed $10 \%$ of the total 
archaeal reads at the genus level. These results are comparable to those obtained for Turkish salterns of similar salinity (Çinar and Mutlu 2016) and significantly lower than that for the Spanish SS13 saltern (Fernández et al. 2014), where as much as $92 \%$ of archaeal sequences were not classified at genus level.

The genus Salinibacter comprising the most halophilic bacteria known and sharing many properties with halophilic Archaea such as Haloquadratum has been shown to be a dominant member of some crystallizer communities, e.g., Fadlum (Çinar and Mutlu 2016) or SS19 and SS37 in Santa Pola salterns (Ghai et al. 2011) and hypersaline lakes, e.g., Tyrrell (Australia), Aran-Bidgol (Iran) (Podell et al. 2014; Makhdoumi-Kakhki et al. 2012). In addition to Salinibacter, representatives of the genera Salisaeta and Euhalothece were among the dominant taxa in Turkish salterns Bingöl and Fadlum (salinity 25 and 27\%, respectively) (Çinar and Mutlu 2016)). Although Salinibacter is an important part of the bacterial communities in hypersaline environments, the 16S rRNA gene reads related to it were not detected in our samples, nor in the Andean saltern described by Maturrano et al. (2006). The lack of genera Salinibacter and also Salisaeta in the system of graduation towers in Ciechocinek could be related with the lower levels of solar radiation and lower temperature, compared to the salterns and lakes where these organisms were detected. Salinibacter and presumably Salisaeta (Schneider et al. 2013) and also Haloquadratum are capable of phototrophic growth and lack of the sunshine in the bottom tanks from which the samples were taken may limit their growth in the multi-species competitive conditions. Instead in the most concentrated sample GT3, a considerable number of reads ( $\sim 18 \%$ of total reads) were assigned to Fodinibius. Members of this genus were first isolated from a salt mine in the Yunnan province China (Wang et al. 2012) but they have never been found yet in abundance in hypersaline environments. Besides Fodinibius in the moderately saline GT2 sample the relatively high proportion of reads was classified as Fabibacter ( 13\% of total reads). Its representatives were isolated from samples of marine origin (Wong et al. 2015) and F. halotolerans showed moderate salt tolerance up to $12 \% \mathrm{NaCl}$.

Although the bacterial and archaeal communities were largely dominated by halotolerant and halophilic microorganisms in all the samples studied, there was a significant difference in the bacterial community structure between the samples. The distinct difference in the bacterial assemblages was most likely caused by salinity changes. The influence of salinity on microbial community composition in various water ecosystems was extensively investigated by other researchers (Jiang et al. 2007; Maturrano et al. 2006; Yang et al. 2016; Zhang et al. 2013). These studies have definitively shown that salinity is one of the most important factors controlling bacterial abundance diversity and metabolic activity exceeding the influence of temperature and $\mathrm{pH}$ (Lozupone and Knight 2007; Wang et al. 2011; Boujelben et al. 2012; Wu et al. 2006). Other factors such as nutrient concentration and organic matter composition gradient also cannot be neglected (Oren 2002).

Major physico-chemical environmental shifts from, e.g., anoxic into oxic conditions have a direct impact on community composition and richness of many organisms (Andrei et al. 2015; Herlemann et al. 2011; Máthé et al. 2014). This could be the second important factor affecting investigated microbiome of graduation towers. The most dramatic change may take place when brine from the borehole containing little or no oxygen enters the first graduation tower GT1 and after passing through it becomes saturated with atmospheric air. Oxygen delivery may affect bacterial and archaeal community structure of GT1 which is unique across the samples. The low solubility of oxygen in salt-saturated brines and the potentially high heterotrophic activity of the dense microbiota often results in a near-anaerobic conditions in the hypersaline environments (Oren 2017) and this can be the reason why GT3 bacterial community is more similar to INT11 community than to GT1.

\section{Conclusions}

The microbial composition of the brines from the system of graduation towers was remarkable. The increasing salts concentration (4.5-27\%) increased the cell counts and diversity of bacterial and archaeal communities. Bacterial communities were generally more diverse than archaeal communities. Both the archaeal and the bacterial community compositions were remarkably different from what was expected. The Haloquadratum and Salinibacter-related sequences which are characteristic for hypersaline environments were absent. A strong increase of the number of novel sequences with increasing salinity was observed indicating that potentially new bacterial taxa inhabit the unique environment of graduation towers.

Acknowledgement This research was supported by funds provided by Nicolaus Copernicus University (Torun Poland) to maintain research potential.

\section{Compliance with ethical standards}

Conflict of interest The authors declare no conflict of interest.

Open Access This article is distributed under the terms of the Creative Commons Attribution 4.0 International License (http://creativecommons.org/licenses/by/4.0/), which permits unrestricted use, distribution, and reproduction in any medium, provided you give appropriate credit to the original author(s) and the source, provide a link to the Creative Commons license, and indicate if changes were made. 


\section{References}

Alm EW, Oerther DB, Larsen N, Stahl DA, Raskin L (1996) The oligonucleotide probe database. Appl Environ Microbiol 62:3557-3559

Andrei A-Ş, Robeson MS, Baricz A, Coman C, Muntean V, Ionescu A, Etiope G, Alexe M, Sicora CI, Podar M, Banciu HL (2015) Contrasting taxonomic stratification of microbial communities in two hypersaline meromictic lakes. ISME J 9:2642-2656

Antón J, Rosselló-Mora R, Rodríguez-Valera F, Amann R (2000) Extremely halophilic bacteria in crystallizer ponds from solar salterns. Appl Environ Microbiol 66:3052-3057

Beaton ED, Stevenson BS, King-Sharp KJ, Stamps BW, Nunn HS, Stuart M (2016) Local and regional diversity reveals dispersal limitation and drift as drivers for groundwater bacterial communities from a fractured granite formation. Front Microbiol 7:1933

Beyer A, Weist A, Brangsch H, Stoiber-Lipp J, Kothe E (2014) Aquifer microbiology at different geogenic settings for environmental biogeotechnology. In: Das S (ed) Microbial biodegradation and bioremediation. Elsevier, Oxford, pp 557-577

Boujelben I, Gomariz M, Martínez-García M, Santos F, Peña A, López C, Antón J, Maalej S (2012) Spatial and seasonal prokaryotic community dynamics in ponds of increasing salinity of Sfax solar saltern in Tunisia. Antonie Van Leeuwenhok 101:845-857

Bray JR, Curtis JT (1957) An ordination of the upland forest communities of southern Wisconsin. Ecol Monogr 27:326-349

Burkowska-But A, Kalwasińska A, Brzezinska M (2014) The role of open-air inhalatoria in the air quality improvement in spa towns. Int J Occup Med Environ Health 27:560-570

Burns DG, Camakaris HM, Janssen PH, Dyall-Smith ML (2004) Combined use of cultivation-dependent and cultivation-independent methods indicates that members of most haloarchaeal groups in an Australian crystallizer pond are cultivable. Appl Environ Microbiol 70:5258-5265

Campbell BJ, Kirchman DL (2013) Bacterial diversity community structure and potential growth rates along an estuarine salinity gradient. ISME J 7:210-220

Casamayor EO, Massana R, Benlloch S, Øvreås L, Díez B, Goddard VJ, Gasol JM, Joint I, Rodríguez-Valera F, Pedrós-Alió C (2002) Changes in archaeal bacterial and eukaryal assemblages along a salinity gradient by comparison of genetic fingerprinting methods in a multipond solar saltern. Environ Microbiol 4:338-348

Cha IT, Yim KJ, Song HS, Lee HW, Hyun DW, Kim KN, Choi JS, Kim D, Lee SJ, Seo MJ, Choi HJ, Bae JW, Rhee SK, Roh SW, Nam YD (2014) Halolamina rubra sp. nov. a haloarchaeon isolated from non-purified solar salt. Antonie Leeuwenhoek 105:907-914

Chao A (1984) Nonparametric estimation of the number of classes in a community. Scand J Stat 11:265-270

Chao A, Lee S-M (1992) Estimating the number of classes via sample coverage. J Am Stat Assoc 87:210-217

Chaudhary A, Haack SK, Duris JW, Marsh TL (2009) Bacterial and archaeal phylogenetic diversity of a cold sulfur-rich spring on the shoreline of Lake Erie Michigan. Appl Environ Microbiol 75:5025-5036

Çinar S, Mutlu MB (2016) Comparative analysis of prokaryotic diversity in solar salterns in eastern Anatolia (Turkey). Extremophiles 20:589-601

Crump BC, Hopkinson CS, Sogin ML, Hobbie JE (2004) Microbial biogeography along an estuarine salinity gradient: combined influences of bacterial growth and residence time. Appl Environ Microbiol 70:1494-1505

Cui HL, Gao X, Yang X, Xu XW (2011) Halolamina pelagica gen nov. sp. nov. a new member of the family Halobacteriaceae. Int J Syst Evol Microbiol 61:1617-1621
DeLong EF (1992) Archaea in coastal marine environments. Proc Natl Acad Sci USA 89:5685-5689

Dillon JG, Carlin M, Gutierrez A, Nguyen V, McLain N (2013) Patterns of microbial diversity along a salinity gradient in the Guerrero Negro solar saltern, Baja CA Sur, Mexico. Front Microbiol 4:399

Dyall-Smith ML, Pfeiffer F, Klee K, Palm P, Gross K, Schuster SC, Rampp M, Oesterhelt D (2011) Haloquadratum walsbyi: limited diversity in a global pond. PLoS ONE 6:e20968

Edgar RC, Haas BJ, Clemente JC, Quince C, Knight R (2011) UCHIME improves sensitivity and speed of chimera detection. Bioinformatics 27:2194-2200

Elshahed MS, Najar FZ, Roe BA, Oren A, Dewers TA, Krumholz LR (2004) Survey of archaeal diversity reveals an abundance of halophilic Archaea in a low-salt sulfide- and sulfur-rich spring. Appl Environ Microbiol 70:2230-2239

Felföldi T, Ramganesh S, Somogyi B, Krett G, Jurecska L, Szabó A, Vörös L, Márialigeti K, Máthé I (2016) Winter planktonic microbial communities in highland aquatic habitats. Geomicrobiol J 33:494-504

Fernández AB, Vera-Gargallo B, Sánchez-Porro C, Ghai R, Papke RT, Rodríguez-Valera F, Ventosa A (2014) Comparison of prokaryotic community structure from Mediterranean and Atlantic saltern concentrator ponds by a metagenomic approach. Front Microbiol $5: 196$

Frontier S (1985) Diversity and structure in aquatic ecosystems. Oceanogr Mar Biol Ann Rev 23:253-312

Fry NK, Fredrickson JK, Fishbain S, Wagner M, Stahl DA (1997) Population structure of microbial communities associated with two deep anaerobic alkaline aquifers. Appl Environ Microbiol 63:1498-1504

Fry JC, Parkes RJ, Cragg BA, Weightman AJ, Webster G (2008) Prokaryotic biodiversity and activity in the deep subseafloor biosphere. FEMS Microbiol Ecol 66:181-196

Ghai R, Pašić L, Fernández AB, Martin-Cuadrado AB, Mizuno CM, McMahon KD, Papke RT, Stepanauskas R, Rodriguez-Brito B, Rohwer F, Sánchez-Porro C, Ventosa A, Rodríguez-Valera F (2011) New abundant microbial groups in aquatic hypersaline environments. Sci Rep 1:135

Gołębiewski M, Deja-Sikora E, Cichosz M, Tretyn A, Wróbel B (2014) 16S rDNA pyrosequencing analysis of bacterial community in heavy metals polluted soils. Microb Ecol 67:635-647

Gomariz M, Martínez-García M, Santos F, Rodriguez F, CapellaGutiérrez S, Gabaldón T, Rosselló-Móra R, Meseguer I, Antón J (2015) From community approaches to single-cell genomics: the discovery of ubiquitous hyperhalophilic Bacteroidetes generalists. ISME J 9:16-31

Gooddy DC, Hinsby K (2008) Organic quality of groundwaters. In: Edmunds WM, Shand P (eds) Natural groundwater quality. Blackwell Publishing Ltd, Singapore, pp 59-71

Guixa-Boixareu N, Calderón-Paz JI, Heldal M, Bratbak G, Pedrós-Alió C (1996) Viral lysis and bacterivory as prokaryotic loss factors along a salinity gradient. Aquat Microb Ecol 11:215-227

Harding T, Brown MW, Simpson AG, Roger AJ (2016) Osmoadaptative strategy and its molecular signature in obligately halophilic heterotrophic protists. Genome Biol Evol 8:2241-2258

Harrell FE (2016) Package 'Hmisc': Harrell miscellaneous Version 40-0 https://github.com/harrelfe/Hmisc. Accessed 15 Aug 2017

Herlemann DP, Labrenz M, Jürgens K, Bertilsson S, Waniek JJ, Andersson AF (2011) Transitions in bacterial communities along the $2000 \mathrm{~km}$ salinity gradient of the Baltic Sea. ISME J 5:1571-1579

Horn HS (1966) Measurement of "overlap" in comparative ecological studies. Am Nat 100:419-424 
Hoshino T, Morono Y, Terada T, Imachi H, Ferdelman TG, Inagaki F (2011) Comparative study of subseafloor microbial community structures in deeply buried coral fossils and sediment matrices from the challenger mound in the porcupine seabight. Front Microbiol 2:231

Ivanova EP, Bowman JP, Christen R, Zhukova NV, Lysenko AM, Gorshkova NM, Mitik-Dineva N, Sergeev AF, Mikhailov VV (2006) Salegentibacter flavus sp. nov. Int J Syst Evol Microbiol 56:583-586

Jiang H, Dong H, Yu B, Liu X, Li Y, Ji S, Zhang CL (2007) Microbial response to salinity change in Lake Chaka a hypersaline lake on Tibetan plateau. Environ Microbiol 9:2603-2621

Kalwasińska A, Felföldi T, Walczak M, Kosobucki P (2015) Physiology and molecular phylogeny of bacteria isolated from alkaline distillery lime. Pol J Microbiol 64:369-377

Knauss KG, Wolery TJ, Jackson KJ (1990) A new approach to measuring $\mathrm{pH}$ in brines and other concentrated electrolytes. Geochim Cosmochim Acta 54:1519-1523

Kozich JJ, Westcott SL, Baxter NT, Highlander SK, Schloss PD (2013) Development of a dual-index sequencing strategy and curation pipeline for analyzing amplicon sequence data on the MiSeq Illumina sequencing platform. Appl Environ Microbiol 79:5112-5120

Krawiec A (1999) New results of the isotope and hydrogeological investigations of therapeutical waters of Ciechocinek spa (in Polish with English summary). Przegl Geol 47:255-260

Krawiec A (2009) Wody termalne w uzdrowisku Ciechocinek. Tech Posz Geol 48:73-80

Kunin V, Engelbrektson A, Ochman H, Hugenholtz P (2010) Wrinkles in the rare biosphere: pyrosequencing errors can lead to artificial inflation of diversity estimates. Environ Microbiol 12:118-123

Lê S, Josse J, Husson F (2008) FactoMineR: an R package for multivariate analysis. J Stat Softw 25:1-18

Lee JC, Kim YS, Yun BS, Whang KS (2015) Idiomarina halophila sp. nov. isolated from a solar saltern sediment. Int J Syst Evol Microbiol 65:1268-1273

Lovley DR, Goodwin S (1988) Hydrogen concentrations as an indicator of the predominant terminal electron-accepting reactions in aquatic sediments. Geochim Cosmochim Acta 52:2993-3003

Lozupone CA, Knight R (2007) Global patterns in bacterial diversity. Proc Natl Acad Sci USA 104:11436-11440

Ma Y, Galinski EA, Grant WD, Oren A, Ventosa A (2010) Halophiles 2010: life in saline environments. Appl Environ Microbiol 76:6971-6981

Makhdoumi-Kakhki A, Amoozegar MA, Ventosa A (2012) Salinibacter iranicus sp. nov. and Salinibacter luteus sp. nov., isolated from a salt lake, and emended descriptions of the genus Salinibacter and of Salinibacter ruber. Int J Syst Evol Microbiol 62:1521-1527

Máthé I, Borsodi AK, Tóth EM, Felföldi T, Jurecska L, Krett G, Kelemen Z, Elekes E, Barkács K, Márialigeti K (2014) Vertical physico-chemical gradients with distinct microbial communities in the hypersaline and heliothermal Lake Ursu (Sovata Romania). Extremophiles 18:501-514

Maturrano L, Santos F, Rosselló-Mora R, Antón J (2006) Microbial diversity in Maras salterns a hypersaline environment in the Peruvian Andes. Appl Environ Microbiol 72:3887-3895

Moss JA, Nocker A, Lepo JE, Snyder RA (2006) Stability and change in estuarine biofilm bacterial community diversity. Appl Environ Microbiol 72:5679-5688

Ochsenreiter T, Pfeifer F, Schleper C (2002) Diversity of Archaea in hypersaline environments characterized by molecular-phylogenetic and cultivation studies. Extremophiles 6:267-274

Oksanen J, Blanchet FG, Friendly M, Kindt R, Legendre P, McGlinn D, Minchin PR, O'Hara RB, Simpson GL, Solymos P, Stevens MHH, Szoecs E, Wagner H (2017) vegan: community ecology package $\mathrm{R}$ version 24-3 https://github.com/vegandevs/vegan. Accessed 15 Aug 2017
Oren A (2002) Molecular ecology of extremely halophilic archaea and bacteria. FEMS Microbiol Ecol 39:1-7

Oren A (2008) Microbial life at high salt concentrations: phylogenetic and metabolic diversity. Saline Syst 4:2

Oren A (2017) Glycerol metabolism in hypersaline environments. Environ Microbiol 19:851-863

Oren A, Duker S, Ritter S (1996) The polar lipid composition of walsby's square bacterium. FEMS Microbiol Lett 138:135-140

Øvreås L, Daae FL, Torsvik V, Rodriguez-Valera F (2003) Characterization of microbial diversity in hypersaline environments by melting profiles and reassociation kinetics in combination with terminal restriction fragment length polymorphism (T-RFLP). Microb Ecol 46:291-301

Park SJ, Cha IT, Kim SJ, Shin KS, Hong Y, Roh DH, Rhee SK (2012) Salinisphaera orenii sp. nov. isolated from a solar saltern. Int J Syst Evol Microbiol 62:1877-1883

Park S, Jung YT, Park JM, Kim SG, Yoon JH (2016) Psychroflexus aestuariivivens $\mathrm{sp}$. nov. isolated from a tidal flat. Int J Syst Evol Microbiol 66:2146-2151

Pedersen K, Ekendahl S (1990) Distribution and activity of bacteria in deep granitic groundwaters of southeastern Sweden. Microb Ecol 20:37-52

Podell S, Emerson JB, Jones CM, Ugalde JA, Welch S, Heidelberg KB, Banfield JF, Allen EE (2014) Seasonal fluctuations in ionic concentrations drive microbial succession in a hypersaline lake community. ISME J 8:979-990

Purkamo L, Bomberg M, Kietäväinen R, Salavirta H, Nyyssönen M, Nuppunen-Puputti M, Ahonen L, Kukkonen I, Itävaara M (2016) Microbial co-occurrence patterns in deep Precambrian bedrock fracture fluids. Biogeosciences 13:3091-3108

Quast C, Pruesse E, Yilmaz P, Gerken J, Schweer T, Yarza P, Peplies J, Glöckner FO (2013) The SILVA ribosomal RNA gene database project: improved data processing and web-based tools. Nucleic Acids Res 41:D590-D596

Schloss PD, Westcott SL, Ryabin T, Hall JR, Hartmann M, Hollister EB, Lesniewski RA, Oakley BB, Parks DH, Robinson CJ, Sahl JW, Stres B, Thallinger GG, Van Horn DJ, Weber CF (2009) Introducing mothur: open-source platform-independent communitysupported software for describing and comparing microbial communities. Appl Environ Microbiol 75:7537-7541

Schneider D, Arp G, Reimer A, Reitner J, Daniel R (2013) Phylogenetic analysis of a microbialite-forming microbial mat from a hypersaline lake of the Kiritimati atoll Central Pacific. PLoS ONE 8:e66662

Szabó A, Korponai K, Kerepesi C, Somogyi B, Vörös L, Bartha D, Márialigeti K, Felföldi T (2017) Soda pans of the Pannonian steppe harbor unique bacterial communities adapted to multiple extreme conditions. Extremophiles 21:639-649

Tindall BJ, Rosselló-Móra R, Busse HJ, Ludwig W, Kämpfer P (2010) Notes on the characterization of prokaryote strains for taxonomic purposes. Int J Syst Evol Microbiol 60:249-266

Trigui H, Masmoudi S, Brochier-Armanet C, Barani A, Grégori G, Denis M, Dukan S, Maalej S (2011) Characterization of heterotrophic prokaryote subgroups in the Sfax coastal solar salterns by combining flow cytometry cell sorting and phylogenetic analysis. Extremophiles 15:347-358

Ventosa A, de la Haba RR, Sánchez-Porro C, Papke RT (2015) Microbial diversity of hypersaline environments: a metagenomic approach. Curr Opin Microbiol 25:80-87

Walczak M, Deja-Sikora E, Kalwasińska A, Polatowski M, Krawiec A (2017) Distribution of bacteria in the mineral waters found in the Polish Lowland. Geol Q 61:177-185

Wang J, Yang D, Zhang Y, Shen J, van der Gast C, Hahn MW, Wu Q (2011) Do patterns of bacterial diversity along salinity gradients differ from those observed for macroorganisms? PLoS One 6:e27597 
Wang YX, Liu JH, Xiao W, Zhang XX, Li YQ, Lai YH, Ji KY, Wen ML, Cui XL (2012) Fodinibius salinus gen nov. sp. nov a moderately halophilic bacterium isolated from a salt mine. Int J Syst Evol Microbiol 62:390-396

Wei T, Simko V (2016) Package 'corrplot': visualization of a correlation matrix R Version 077 https://github.com/taiyun/corrplot. Accessed 15 Aug 2017

Wong SK, Park S, Lee JS, Lee KC, Chiura HX, Kogure K, Hamasaki K (2015) Fabibacter misakiensis sp. nov. a marine bacterium isolated from coastal surface water. Int J Syst Evol Microbiol 65:3276-3280

Wu QL, Zwart G, Schauer M, Kamst-van Agterveld MP, Hahn MW (2006) Bacterioplankton community composition along a salinity gradient of sixteen high-mountain lakes located on the Tibetan Plateau China. Appl Environ Microbiol 72:5478-5485

Xing P, Hahn MW, Wu QL (2009) Low taxon richness of bacterioplankton in high-altitude lakes of the eastern tibetan plateau with a predominance of Bacteroidetes and Synechococcus spp. Appl Environ Microbiol 75:7017-7025

Yang J, Ma L, Jiang H, Wu G, Dong H (2016) Salinity shapes microbial diversity and community structure in surface sediments of the Qinghai-Tibetan Lakes. Sci Rep 6:25078
Yoon JH, Lee MH, Kang SJ, Oh TK (2008) Salegentibacter salinarum sp. nov., isolated from a marine solar saltern. Int J Syst Evol Microbiol 58:365-369

Zajc J, Liu Y, Dai W, Yang Z, Hu J, Gostinčar C, Gunde-Cimerman N (2013) Genome and transcriptome sequencing of the halophilic fungus Wallemia ichthyophaga: haloadaptations present and absent. BMC Genom 14:617

Zhang L, Gao G, Tang X, Shao K, Bayartu S, Dai J (2013) Bacterial community changes along a salinity gradient in a Chinese wetland. Can J Microbiol 59:611-619

Zhong ZP, Liu Y, Liu HC, Wang F, Zhou YG, Liu ZP (2015) Marinobacter halophilus sp nov a halophilic bacterium isolated from a salt lake. Int J Syst Evol Microbiol 65:2838-2845

Zhou J, Bruns MA, Tiedje JM (1996) DNA recovery from soils of diverse composition. Appl Environ Microbiol 62:316-322

Zuber A, Grabczak J (1991) On the origin of saline waters in the Mesozoic of central and northern Poland (in Polish). Współczesne Problemy Hydrogeologii, SGGW-AR Warsaw, pp 202-208

Zuber A, Różański K, Ciężkowski W (2007) Metody znacznikowe w badaniach hydrogeochemicznych. Oficyna Wydawnicza Politechniki Wrocławskiej, Wrocław 